\title{
Eskatologie in die Evangelie van Lukas
}

\begin{abstract}
Eschatology in the Gospel of Luke

In unfolding his eschatology the author of the Gospel of Luke acknowledges that the final fate of mankind and of the world has not come about and that the Christians are still waiting for the parousia of the Son of man. The eschatology of Luke is primarily determined by quality and not so much by time. Eschatological life means to live as if Jesus could come at any time. This means that in terms of time eschatology is absorbed in ethics. Apart from that the eschatological thinking is developed as part of Luke's Christological thinking.
\end{abstract}

\section{1. 'ESKATOLOGIE'}

Die term 'eskatologie' is in die 17e eeu vir die eerste keer gebruik.2 Van toe af tot en met die Dialektiese Teologie was die bedoeling duidelik en ondubbelsinnig: dit is gebruik om te verwys na dogmatiese leerstellings 'oor die eindtye' (de novissimis) en die opvattings aangaande die finale lot van die individu ('individuele eskatologie'), van die mensdom ('kollektiewe/universele eskatologie'), en van die wêreld ('kosmiese eskatologie').3 Binne die Joods-Christelike tradisie sluit hierdie opvattings onder andere in: die na-doodse lot van die individu; die herstel van God se uitverkorenes; die opstanding uit die dood; die finale oordeel; die koms van die Messias - die parousia van die verheerlikte Here; die hernuwing van hemel en aarde; en - soos Niebuhr op 'n keer gespot het - 'the furniture of heaven and the temperature of hell'.4

Binne hierdie konteks is die betekenisse van 'finale einde' en 'finale/laaste dinge' nogal dubbelsinnig, aangesien tyd nie tot 'n finale einde gaan kom nie, maar gaan voortgaan. Om hierdie rede is dit veel meer gepas om 'eskatologie' te verstaan as verwysing na 'voltooiing' of 'voleindiging': ${ }^{5}$ hierdie term verwys na 'n versameling van konsepte wat verwys na die voltooide/voleindigde toestand van die individu/mensdom/die wêreld; en na die gebeure wat hierdie toestand teweeg gaan bring. Die terme 'voleindiging' en 'voltooiing' dui op 'n status wat nooit sal verander nie en vir ewig sal aanhou; asook die gebeure wat dit teweeg bring. 'Die ewigheid' beteken binne hierdie verband nie dat 'tyd' tot ' $n$ einde gekom het nie, maar dat ' $n$ sekere toestand tot stand gekom het wat nooit weer sal verander nie. Slegs op hierdie manier kan die eindgebeure 'finaal' genoem word; wanneer 'eskatologie' nie bepaal word deur tyd nie, maar kwaliteit.

Dit is met presies hierdie aspek wat die Dialektiese Teologie vasdraai: met die veronderstelling

1 Universiteit van Bonn en Navorsingsamewerker Noord-Wes Universiteit (Potchefstroom Kampus)

2 ' $n$ Geskiedenis hieroor is geskryf deur Hjelde (1987).

3 Hierdie onderskeid volg dié van Filoramo (1999, 1542).

4 Die oorsprong van hierdie frase is onbekend. Die presiese bewoording is: 'It is unwise for Christians to claim any knowledge of either the furniture of heaven or the temperature of hell'. Alhoewel dit gereeld aangehaal word uit Niebuhr, word 'n verwysing nooit voorsien nie (vgl. bv. Sauter 1995, 4; Dixon 2003, 25).

5 Vgl. bv., Härle (1995, 600): 'Die Eschatologie als die Lehre der - von Gott her - vollendeten Welt'. 
dat eskatologie die konseptualisering is van 'n voleindigde kwaliteit, d.i. van 'n gefinaliseerde realiteit wat nooit weer verander kan word nie; daar word aanspraak gemaak daarop dat 'n Christelike eskatologie moet aandring daarop dat die finale einde reeds gekom het, naamlik in die koms van Jesus Christus (ten opsigte van universele- en kosmiese eskatologie) en in ' $n$ ontmoeting met Hom (ten opsigte van individuele eskatologie). Ten opsigte van eersgenoemde, kan hierdie nuwe bepaling van wat 'eskatologie' is, geïllustreer word met Barth $(1933,500)$ se beroemde woorde:

The End of which the New Testament speaks is no temporal event, no legendary 'destruction' of the world; it has nothing to do with any historical, or 'telluric', or cosmic catastrophe. The end of which the New Testaments speaks is really the End; so utterly the End, that in the measuring of nearness or distance our nineteen hundred years are not merely of little, but of no importance; so utterly the End that Abraham already saw the Day - and was glad.

En: 'Christentum, das nicht ganz und gar und restlos Eschatologie ist, hat mit Christus ganz und gar und restlos nichts zu tun'.(Barth 1922, 299).

Ten opsigte van die individuele eskatologie het Bultmann en sy aanhangers die term 'presentic' eskatologie gebruik: in die ontmoeting met die Christelike boodskap (die kerygma), maak jy jou besluit oor jou finale eskatologiese lot. Hieruit vloei dat, vir die gelowige, is geskiedenis beroof van enige teologiese betekenis aangesien dit totaal geabsorbeer is deur die eskatologie:

Christ is the eschatological event not as a figure of the past ... but as the Christus prae-sens ... The paradox of history and eschatology is that the eschatological event has hap-pened within history and happens everywhere in preaching. That means: eschatology in a true Christian understanding of it is not the future end of history, but history is swallowed up by eschatology. Henceforth history must no longer be understood as saving history, but as profane history. But the dialectic of human life as historical existence is brought to light, and in consequence the history of man as person can no longer be understood as a function of world-history, but is set beyond world-history (Bultmann (1954/55, 15-16).

In hierdie opsig het Ebeling $(1979,399)$ 'Christologie' verstaan as 'perfektiese eskatologie' (perfektische Eschatologie). Vir Klein $(1982,270)$ is Christus se sterwe en opstanding 'n 'final event, qualifying time and history' en hy definieer eskatologie as 'expression of an attitude, namely of an understanding of time and history which constitutes early Christian faith' (Klein 1982, 271). Dit beteken dat die persoon wat in Christus glo, het reeds, hier en nou, eskatologiese verlossing (sien Härle 1995, 605) - al is hy of sy steeds gebind binne sy of haar liggaamlike bestaan aan 'n ongeredde, onvoltooide onvoleindigde wêreld. Hierdie toestand veroorsaak 'n spanning wat veral aandag kry binne die Pauliniese briewe, Johannes, Kolossense en Efesiërs. Hierdie siening van die eskatologiese karakter van God se selfontsluiting (Selbsterschließung) in Jesus Christus, en die ontmoeting met die kerygma, beroof tyd en geskiedenis van enige teologiese betekenis. Die gelowige se geloof in Jesus Christus en sy sekerheid dat 'niks in staat is om ons te skei van die liefde van God wat daar is in Christus Jesus, ons Here' (Rom 8:39) nie, veroorsaak dat hy 'eskatologies' bestaan alhoewel sy/haar liggaam en die wêreld om hom/haar steeds wag vir hulle eskatologiese transformasie.

Dit bring ons by nog 'n aspek wat aangespreek moet word in hierdie inleidende opmerkings: alhoewel eskatologiese voltooiing altyd 'n ewigdurende situasie tot gevolg het, beteken dit nie dat van hierdie oomblik af alles voortaan dieselfde sal bly en niks ooit sal verander nie. Om die 
waarheid te sê, ons moet noukeurig definieer wat staan in beskikbare eskatologiese uitsprake naamlik dat dit vir ewig sal aanhou en dat ons moet erken dat kort hiervan is daar altyd plek vir verandering en wysiging.

Laat ek dit illustreer met die volgende voorbeeld: volgens Openbaring 22:5 sal die dienaars van die Here 'reign for ever and ever'; d.i. 'they participate as worshiping servants in the eternal rule of God' (Aune 1998, 1181). Hierdie moet letterlik verstaan word; dat in hierdie spesifieke situasie - die ewigdurende heerskappy van die dienaars van God - wat nooit ooit sal verander nie en dat hierdie heerskappy nooit ooit by hulle weggeneem sal word nie. Die verwagting wat hier uitgespreek word beteken nie dat alles gevries sal word of dat lewe in die Nuwe Jerusalem gaan verander tot ' $n$ eindelose herhaling van heeltyd dieselfde ding nie. Al word die ewigdurende heerskappy van God se dienaars nooit opgehef nie, laat die verwagting wat hier geskep is meer as genoeg ruimte vir diversifikasie en aanpassing van die bestaan van die inwoners van die hemelse Jerusalem.

\section{ESKATOLOGIESE VERWAGTINGS IN LUKAS}

Daar sal eers ' $n$ kort oorsig gegee word van Lukas se eskatologiese verwagtings, waarna aandag gegee sal word aan 'n individuele teks waarin spesifieke en interessante besonderhede van Lukas se eskatologiese verwagtings nagespeur kan word.

Ten opsigte van die toekomstige vervolmaking van die mensdom en die wêreld en die gebeure wat dit teweeg gaan bring, stem Lukas saam met min of meer al die verwagtings wat gevind kan word in die res van die Nuwe-Testamentiese geskrifte.

Volgens Lukas 17:22-37, ${ }^{6}$ 'n teks wat Lukas aanpas uit $Q$, verwag Hy die koms van die Seun van die mens 'soos die weerlig wat uitslaan (en) die hele lugruim van die een kant na die ander verlig' (v. 24). Dit beteken dat die koms van Jesus oral sigbaar sal wees en dat dit die hele wêreld gaan beïnvloed. Daarom is daar geen rede om agter mense aan te loop wat beweer hulle weet die spesifieke plek waar die Seun van die mens gaan verskyn nie. Dit is veral die taalkundige

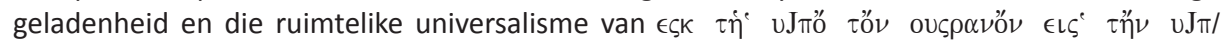
ouৎp $\alpha \nu$ ó $\nu^{7}$ wat die teenstelling aantoon met die bywoorde van plek naamlik; 'daar' en 'hier'.

Die vergelyking van hierdie koms met die koms van die vloed in die dae van Noag en met die koms van die vuur en swael by Sodom in die dae van Lot (verse 26-30) het in gelyke mate beide 'n vertroostende en paranetiese funksie: die volgelinge van Jesus - hetsy die historiese dissipels of die bestemde lesers - word vertroos, want die beskrywing van die toekomstige vernietiging van hulle wat Jesus se boodskap verwerp het, bevestig hulle besluit om die boodskap te aanvaar. Gelyktydig, en dit is veral waar vir die bestemde lesers, word hulle gewaarsku om gereed te wees vir die koms van die Seun van die mens (vgl. ook Nielsen 2000, 205v.).

Die onderskeid tussen 'saamgeneem' ( $\pi \alpha \rho \alpha \lambda \alpha \mu \beta \alpha \dot{\alpha} \nu \sigma \theta \alpha \iota)$ en 'agtergelaat' ( $\alpha \varsigma \phi \epsilon \in \sigma \theta \alpha \iota)$ in verse 34-35 verwys waarskynlik na die feit dat diegene wat gered gaan word van die vernietiging van die wêreld, 'saamgeneem' sal word voor die vernietiging begin. ${ }^{8}$ Hierdie konsep is nie so vêr verwyderd van die verwagting wat veronderstel word in 1 Tessalonisense 4:16-17 nie: hierdie teks verwag dat met die parousia, wanneer die 'Here sal neerdaal uit die hemel', die Christene

6 Vgl. Schnackenburg (1970, 213-234); Rigaux (1970, 407-438); Zmijewski (1972, 326-540); Geiger (1973, 53-149); Friedl (1996).

7 Hierdie Griekse uitdrukking verwys na die totaliteit van die wêreld; vgl. Eksodus 17:14; Deuteronomium 25:19; 29:19; Spreuke 8:26; Job 2:2; 5:10; 9:6; 18:4; 34:13; 38:18, 24; 42:5; Bar 5:3 ('God sal jou heerlikheid openbaar oral onder die hemele'); T. Levi 18:4 (aangaande die messiaanse hoëpriester': 'Hy sal skyn soos die son op die aarde en alle duister onder die hemele verwyder').

8 Vir die vertaal van $\pi \alpha \rho \alpha \lambda \alpha \mu \beta \dot{\alpha} \nu \in \iota \nu$ 'na die hemel', vgl. 2 Hen 17:1; T. Levi 17:4, 6; T. Abr A 15:1; 16:5; vgl. also Friedl 1996, 184vv. 
'saam met hulle op die wolke weggevoer word, die lug in, die Here tegemoet'. In Lukas 17:34-35 kondig Jesus 'n radikale geïndividualiseerde verspreiding van redding en verwerping aan: selfs twee mense wat ten tyde van die parousia so na aan mekaar is soos 'n man en vrou wat saam in die bed lê of twee vroue wat saam meel maal se lot sal verskil.

Die parousia van die Seun van die mens sal voorafgegaan word deur kosmiese tekens:

Daar sal tekens wees aan son, maan en sterre. Op aarde sal daar radeloosheid onder die volke wees uit angs vir die gebulder van die see en sy vloedgolwe. Die mense sal beswyk van vrees en spanning oor die dinge wat oor die hele wêreld aan die kom is, want die kragte van die hemelruim sal ontwrig word. En dan sal hulle die Seun van die mens met groot krag en majesteit op ' $n$ wolk sien kom. As hierdie dinge begin gebeur, staan dan regop en lig julle kop op, want dan is julle verlossing naby (Lukas 21:25-28).

Algemene eskatologiese verwagtings is ook teenwoordig in die jukstaposisie van die saligsprekinge en die weë in Lukas 6:20-26: die algemene koninkryk van God sal 'n omkeer van die goeie en slegte lot van mense teweeg bring. Die armes, hongeres en die onderdruktes sal die rykes en magtiges word en omgekeerd. ' $n$ Individualistiese voorbeeld van hierdie verwagting word ontwikkel in die verhaal van die ryk man en die arme Lasarus in Lukas 16:19-31; en dieselfde konsep word uitgedruk in 18:29-30 met: 'Daar is niemand wat ter wille van die koninkryk van God afgesien het van huis of vrou of broers of ouers of kinders nie, of hy ontvang in hierdie tyd al baie keer soveel terug, en in die tyd wat kom, die ewige lewe'.

Volgens Lukas 12:8-9, 42-46 en 47-48 sal 'n finale oordeel gehou word waar elkeen geoordeel sal word vir sy of haar dade in die breedste sin van die woord; d.i. het hy of sy die Seun van die mens voor ander bely of nie en het hy of sy gedoen wat van hulle verwag is. Buiten dit wys die oordeelstoneel in Lukas 19:16-26 dat Lukas nog steeds 'n oordeel verwag het vir gelowiges volgens hulle dade. Hoewel dit duidelik is dat met hierdie oordeel dit nie die alternatief van verlos of nie is wat ter sprake is nie, maar 'slegs' die eer of 'skaamte' onderskeidelik - om dit te sê in die woorde van 1 Korintiërs 3:14-15; die alternatief van $\mu\llcorner\sigma \theta$ ”ै $\nu \alpha \alpha \mu \beta \dot{\alpha} \nu \epsilon \sigma \theta \alpha \iota$ aan die een kant en $\zeta \eta \mu \iota$ ou $\sigma \alpha \iota$ aan die ander kant. Hier is Lukas se konsep van die oordeel nie vêr van 1 Korintiërs 3:13-15 nie (Konradt 2003, 258vv.); tog verskil dit in karakter van Matteus 25:30, waar die 'nuttelose' slaaf vir ewig verdoem is.

Lukas 20:27-36 verdien ook deeglike aandag; die rede is dat ons in hierdie aankondigingsverhaal van Lukas' $n$ verrassend redelike en oor die algemeen onbekende detail van Lukas se eskatologiese verwagtings vind. Lukas het hierdie verhaal oorgeneem uit Markus 12:18-27. Die verhaal handel oor die verwagting van die eskatologiese opstanding uit die dode; en die Sadduseërs skep 'n fiktiewe verhaal om hierdie verwagting te bring tot ad absurdum. Hulle vrae veronderstel ' $n$ verwagting wat vandag nog algemeen onder Christene geglo word: baie mense verwag dat met die opstanding na die dood 'n herstel van die voor-doodse omstandighede sal plaasvind. In Lukas, is Jesus se reaksie die volgende: 


\begin{tabular}{|c|}
\hline 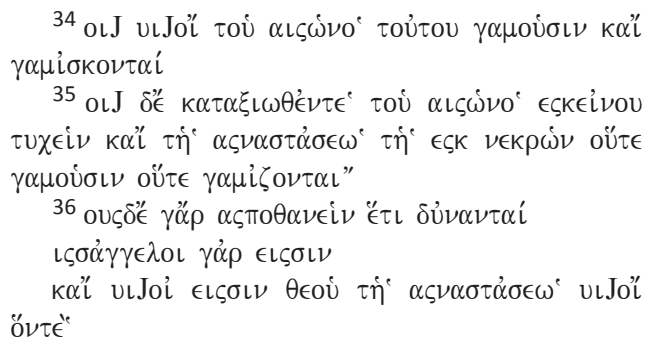 \\
\hline
\end{tabular}

34 Jesus sê vir hulle: "In hierdie wêreld trou die mense met mekaar,

35 maar dié wat waardig geag is om deel te hê aan die toekomstige wêreld en aan die opstanding uit die dood, trou daar nie meer nie.

${ }^{36}$ Hulle kan ook nie meer sterwe nie; hulle is soos die engele. Hulle is kinders van God, omdat hulle uit die dood opgestaan het.

Lukas se byvoeging tot sy Vorlage is in kursief. Dit is ' $n$ duidelike aanduiding van die spesifieke profiel van Lukas se eskatologiese konsep: hy maak dit duidelik dat die vraag van die Sadduseërs belaglik is, aangesien daar na die opstanding uit die dood geen seksuele omgang meer sal

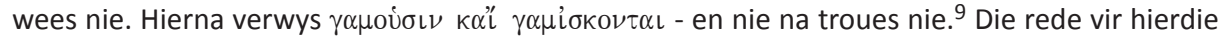
verandering in die omgang tussen man en vrou is voor die hand liggend: die opgestanes sal nooit meer sterf nie, maar vir altyd leef. Daarom is daar geen rede meer om die voortbestaan van die mensdom te verseker deur voortplanting nie. Dit is dus nie die verwagting van die opstanding wat absurd is nie, maar die vraag van die Sadduseërs, want dit is gebaseer op die veronderstelling dat die opgestanes nog seksuele omgang nodig sou hê. Hulle is in hierdie opsig 'soos engele'

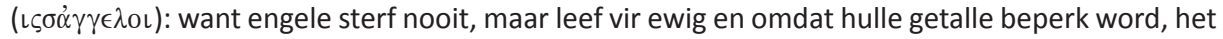
hulle geen nodigheid vir seks nie.

Dit is interessant om te besef dat hierdie eskatologiese konsep ' $n$ onderliggende teologiese verband het met Genesis 3 en die verhaal van die sondeval, wat versteekte seksuele betekenis het. Die verhaal draai om die feit dat Adam en Eva seksualiteit ontdek het: uit 2 Samuel 19:32$35^{10}$ is dit duidelik dat om 'goed en kwaad' te ken (Gen 3:5) 'n eufemisme is vir die vermoë om seksuele omgang te hê. ${ }^{11}$ Die slang belowe vir Eva 'julle (m.a.w. sy en Adam) sal soos God wees' - hierdie verwys na die vermoë om mense te maak. Dienooreenkomstig, nadat Adam en Eva die vrug eet, 'besef hulle dat hulle kaal is' en was hulle skaam vir mekaar (3:7; vgl. 2:25). In 3:22 regverdig God hulle verbanning uit die tuin deur vir Homself te sê: 'Die mens het nou soos een van Ons geword deurdat hy alles kan ken. As hy nou maar net nie sy hand uitsteek en die vrug van die boom van die lewe vat en daarvan eet en altyd bly lewe nie'. Hierna kom dit as geen verassing dat die eerste ding wat Adam en Eva doen na hulle verbanning uit die tuin, is om voort te plant nie (Gen 4:1-2). Genesis 3:1-4:2 en Lukas 20:27-36 is verbind aan mekaar deur die fundamentele menslike besef dat "̈́ $\rho \omega^{\circ}$ en $\theta \dot{\alpha} \nu \alpha \tau 0^{\circ}$ onskeibaar aan mekaar verbind is.

Laat ons nou beweeg na daardie aspekte van die eskatologie wat uniek aan die evangelie van Lukas is, en as gevolg daarvan die fokus is van ons belangstelling.

9 Die betekenis van $\gamma \alpha \mu \in i \nu$ as verwysend na seksuele omgang word bewys in Lukas 17:27 en 1 Timoteus 4:3; Anthol. Graeca 5: 94; Ps. Lukian, Asin. 32; Callimachus, Hymn. Del. 240f; Xanthus, FGH 3c, 765; Frgm. 31; Philo, Cher. 92. Sien ook Liddell, Scott \& Jones ${ }^{9}$ (1992), s.v. $\gamma \alpha \mu$ 'є $\omega$ I.2: 'van blote seksuele omgang'; van Tilborg (2002, 802-810).

10 Hier sê Dawid vir die 80-jarige Barsillai: 'Kom oor na my toe en ek sal vir jou sorg in Jerusalem aan my sy'. Barsillai antwoord: 'Hoeveel jaar het ek nog om te leef dat ek sou opgaan met die koning na Jerusalem? Vandag is ek 80 jaar oud; kan ek onderskei tussen goed en sleg? Kan u dienaar proe wat hy eet of drink? Kan ek nog luister na die stemme van singende mans of vroue? Hoekom dan sou u dienaar ' $n$ ekstra las wees vir my koning en heer?'

11 Vgl. ook Engnell (1955, 115); Michel (1968, 114vv.); Westermann (1984, 243v.). 


\section{DIE ESKATOLOGIESE KARAKTER VAN JESUS SE BEDIENING}

Die soektog vir Lukas se eskatologie is vir dekades gevorm deur Conzelmann se invloedryke studie oor die teologie van Lukas (The Theology of St Luke), ${ }^{12}$ gepubliseer in 1960 . Volgens hom het Lukas die vroeg Christelike eskatologie vervang met die teologiese konsep van Heilsgeschichte (verlossingsgeskiedenis). ${ }^{13} \mathrm{Hy}$ - Lukas - het die verlossingsgeskiedenis ingedeel in drie tydgleuwe: die era van Israel, wat strek tot by en met Johannes die Doper; die era van Jesus; en die era van die kerk. Die era van Jesus ('die middelpunt van tyd' in die oorspronklike Duitse boek), wat hierdie artikel op fokus, was volgens Conzelmann gekarakteriseer deur Lukas as vry van die invloed van Satan, soos hy aangedui het deur te verwys na Lukas 4:13 en 22:3. Tesame met hierdie siening van die verhaal van Jesus gaan ' $n$ 'greater awareness that the events of Jesus lie in the past' (Tuckett 1996, 34v.). Vanuit die perspektief van die skrywer en die lesers van die Lukas evangelie wat geleef het in die era van die kerk, is die verhaal van Jesus nie eskatologie nie, maar geskiedenis. Die soektog na die eskatologie in die evangelie van Lukas is dus oorgedra op die soeke na tyd en die uitstel van die parousia.

Ek wil nie betrokke raak by 'n diskussie oor of Conzelmann reg is of nie, of in watter mate hy reg is nie; ek wil slegs my eie standpunt teenoor syne stel. My interpretasie is gebou op twee basiese veronderstelllings:

Vir Lukas behoort die verlossingsgeskiedenis; d.i. die geskiedenis wat geïnterpreteer word as gerig deur God; nie in drie dele verdeel nie (soos Conzelmann aanneem) en ook nie in twee dele nie (soos sommige van Conzelmann se teenstanders beweer nie). ${ }^{14}$ Hierteenoor moet daar vasgehou word aan die feit dat die Lukasverhaal deel is van 'n enkele oorkoepelende geskiedenis; wat begin met die vaders van Israel (vgl. Hand 7:2; 13:17); aangaan verby Jesus (Hand 13:23) tot by die lesers van Lukas-Handelinge; en steeds aangaan: die geskiedenis van Israel as die geskiedenis van die uitverkorenes van God. Dit is die geskiedenis waarvan 'n greep vertel word in Lukas se twee volume werk, met die intensie om te verduidelik hoe Israel die ongewone vorm aangeneem het wat dit tans het: sommige glo in Jesus en ander nie (Wolter 2008, 26vv.). Slegs onder hierdie vlak kan ons in Lukas se konsep van die geskiedenis twee groot bewegings waarneem van aankondiging tot vervulling: van die geskrifte tot by Jesus (vgl. Luk 4:21; 24:2527:44); en van die tyd van Jesus tot die tyd van die getuies (vgl. Luk 2:34; 24:47-49). ${ }^{15}$

Die eerste deel van hierdie greep uit die geskiedenis van Israel, die storie van Jesus, word vertel deur Lukas as verhaal uit die verre verlede. Lukas se verhaal is nie so inklusief soos die evangelies van Matteus en Johannes nie. Lukas se interpretasie van die verhaal aan die ander kant, wys duidelik dat hy aanspraak daarop maak dat hy eskatologiese gebeure oorvertel. In Lukas se evangelie sien ons oorvertelde eskatologie, en dit is hierdie stelling wat ek wil bewys met die volgende:

Aan die begin van sy verhaal, die geboorteverhaal in Lukas 1-2, mobiliseer Lukas die betroubare karakters van Gabriël, Maria, Sagaria, Simeon en Hanna as interpreteerders van God se inisiatiewe om Johannes en Jesus op te rig as 'profeet van die Allerhoogste' (1:76) en as 'horing van heil' (1:69 OV), die vervulling van Israel se eskatologiese hoop. Johannes se bediening word geplaas teen die interpretatiewe agtergrond van Maleagi 3:1 en 4:5; aangesien hy beskryf word as die een wat die Here moet vooruitgaan met die krag van Elia $(1: 17,76)$. Wat

12 London $1960=1982$; Duitse oorspronklike 1977.

13 Vir 'n kort oorsig van Conzelmann se siening vgl. Tuckett (1996, 33v.).

14 Vgl. bv., Kümmel (1972, 158); Schneider (1980, 136v.); Korn (1993, 272).

15 D.i. van Lukas 24:48 tot Handelinge 26:29. Ek beskou hierdie tekste as beperking van die tydperk van die getuies want Lukas 24:48 is die eerste keer, en Handelinge 26:22 die laaste keer, wat die term $\mu \dot{\alpha} \rho \tau \nu^{\circ}$ voorkom in Lukas-Handelinge (vgl. Wolter 2008, 791). 
Jesus betref, die eskatologiese karakter van God se inisiatief word veral uitgedruk in 1:54, waar Maria Gabriël se aankondiging interpreteer deur die woorde van Jesaja 41:8-9 as vervulling van

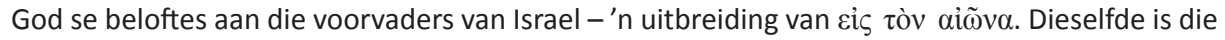
geval met Sagaria se seën: God wat Jesus oprig as die 'horing van heil uit die huis van Dawid' (1:69 OV) is 'n eskatologiese gebeurtenis omdat dit redding bring 'uit die hand van ons vyande, (en ons) Hom sonder vrees kan dien, in heiligheid en geregtigheid voor Hom, al die dae van

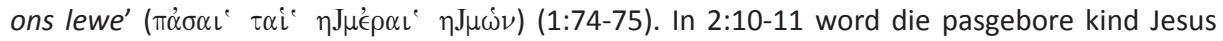
geïdentifiseer aan die skaapwagters as die lang-verwagte eskatologiese verlosser van Israel, die messiaanse koning. Lukas vertel die hele verhaal met behulp van motiewe en sinspelings op die Goue-eeu-eskatologie van die Romeinse Herderspoësie Tradisie (Wolter 2000, 501-517). Die verband met die eerste Herdersdig van Calpurnius wat kommentaar lewer op die begin van die regering van Nero wat die Goue eeu sou inlei is duidelik: twee skaapwagters vind ' $n$ inskripsie by Faunus, die god van skaapwagters en die landvolk. Dit openbaar dat die regering van Nero die Goue eeu teweeg sal bring (v. 42). Die skaapwagters en al die nasies word aangespoor tot blydskap (gaudete: v. 36; 'exsultet quaecumque...gens': v. 74) en 'veilige vrede' (secura pax) word aangekondig (v. 42). Hierby moet onthou word dat Lukas 2:9 se 'en die heerlikheid van die Here het rondom hulle geskyn' laat die lesers God se eskatologiese beloftes in Jesaja 35:2 en 40:5 onthou; en Jesaja 60:1 en 19 sluit in sy glorie op aarde.

Binne die korpus van die Lukas narratief word hierdie gedagtelyn voortgesit in Jesus se eie interpretasie van sy bediening deur sy sinspeling op en aanhaling van profetiese beloftes. In sy Inwydingsboodskap, gelewer in die sinagoge van Nasaret, haal Lukas se Jesus nie net Jesaja 61:1-2 en 58:6 aan nie (Luk 4:18-19), maar deur sy kommentaar in vers 21 ('Vandag is hierdie Skrifwoord wat julle nou net gehoor het, vervul') dui Hy ook aan dat die doel van sy bediening niks anders is nie as die teweeg bring van die eskatologiese transformasie van ellende na verlossing wat God beloof het vir sy volk. In 7:22 sinspeel die Lukaanse op 'n reeks tekste uit Jesaja, waar God se eskatologiese ingryping tot die voordeel van Israel aangekondig word en hy maak aanspraak daarop dat dit sy, Jesus, se bediening is wat hierdie aankondigings verwesenlik; Hy maak sy teenwoordigheid die teenwoordigheid van God se eskatologiese teenwoordigheid aan sy volk, aangesien dit aangekondig word in Sagaria 1:78 en deur die publiek gesê word in 7:16. Lukas 11:20 stem hiermee ooreen ('Aangesien Ek dus deur die vinger van God bose geeste uitdryf, het die koninkryk van God inderdaad tot by julle gekom'); en veral 17:20-21, waar Jesus antwoord op die vraag van die Fariseër oor wanneer die koninkryk van God sou kom, d.i. die vraag oor die tyd van die koninkryk - deur te verwys na die kwaliteit daarvan: 'Die koms van die koninkryk van God kan nie uit voortekens bereken word nie. Hulle sal nie kan sê: "Kyk, hier is dit!" of: "Daar is dit!" nie, want die koninkryk van God is hier by julle'. ${ }^{16}$ Hierdie is - aangesien ons die stelling moet interpreteer - deur die teenwoordigheid en bediening van Jesus.

By hierdie tekste kan ons voeg Lukas 10:1, 9; waar Jesus sy dissipels stuur 'na elke dorp en plek waarheen Hy van plan was om te gaan' en hulle instruksie gegee het om te sê: 'Vir julle is die koninkryk van God baie naby!'. Dit is deur niks anders as deur Jesus se eie teenwoordigheid wat die koninkryk van God teenwoordig sal wees by die mense nie.

Hierdie eskatologiese konsep van Lukas is vorm gegee en van 'n fondasie voorsien deur ' $n$ kenmerkende Christologie: alhoewel Lukas nie Jesus en God met mekaar identifiseer nie - God bly altyd die Vader en Jesus die Seun - skep hy 'n vae nabyheid tussen hulle. Volgens 1:76 sal Johannes 'voor die kúpıo' uitgaan om sy pad gereed te maak'; en daar is geen twyfel dat dit God is van wie Lukas se Sagaria hier praat nie, waar dit eintlik Jesus se weg is wat Johannes gaan gereed maak. Dieselfde vae prentjie, waar dit onmoontlik is vir die leser om onderskeid te tref tussen God en Jesus, is die aanhaling van Jesaja 40:3-5 in Lukas 3:4-6; en die sinspeling op 
Maleagi 3:1; en 4:5 in 1:17. hierby moet ons voeg 'n feit wat besonders is aan Lukas onder die Sinoptiese Evangelies: Jesus word kủpıo' genoem nie net deur die karakters in die narratief nie, maar ook deur die verteller self. ${ }^{17}$ Dit is definitief nie per ongeluk dat Lukas hierdie gebruik begin in 7:13, waar Jesus die weduwee se seun uit die dood opwek nie.

Die gevolg van hierdie eskatologiese aard van Jesus se bediening is dat 'n ontmoeting met Hom eskatologiese gevolge het. Verlossing en veroordeling by die finale oordeel, wat nog moet kom, hang af van hoe mense gereageer het op Jesus se boodskap en implisiete Christologiese aanspraak. Die mees insiggewende teks is sonder twyfel 13:23-28 waar die Lukaanse Jesus vertel van 'n toekomstige situasie waar 'baie' (

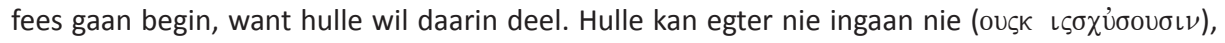
want die deur is gesluit en die eienaar weier hulle toegang. Die rede word weergegee in $\alpha \varsigma \gamma \nu \omega \nu i \zeta \epsilon \sigma \theta \epsilon \in \iota \varsigma \sigma \epsilon \lambda \theta \epsilon i \nu$ aan die begin van vers 24: hulle het nie daarna gestreef om deur die smal deur in te gaan waaragter die eskatologiese fees plaasvind nie. Die imperatief $\alpha \varsigma \gamma \nu \omega \nu i \zeta \epsilon \sigma \theta \epsilon$ verseker dat dit reeds in die teenwoordigheid van Jesus is waar die besluit geneem word oor wie deur die smal deur sal ingaan in die huis waar die eskatologiese maaltyd aangebied sal word, en wie verwerp sal word. Ek kan nie enige verskil sien tussen die interne struktuur van hierdie eskatologiese denke en die van Johannes 5:24 nie.

Hierdie metaforiese wyse van eskatologiese konseptualisering het sy nie-metaforiese parallel in ' $n$ ander groep tekste: die weë teen Gorasin en Betsaida in 10:13, want hulle weiering om in sak en as te sit en berou te toon is sematies gelyk aan die weiering van $\alpha \alpha \varsigma \gamma \nu \omega \nu i \zeta \epsilon \sigma \theta \epsilon \epsilon \iota \zeta \sigma \epsilon \hat{\lambda}$ $\theta \in i \nu$ in 13:24. Dieselfde is waar vir 'hierdie generasie' in 11:29-32, of volgens 13:1-5 vir hulle wat weier om hulle te bekeer. Die klimaks van Jesus se bediening en die sleutel tot die verstaan van sy eskatologiese impak is egter ' $n$ ander gebeurtenis: sy opstanding.

\section{DIE KLIMAKS VAN JESUS SE BEDIENING: SY ESKATOLOGIESE TROONBESTYGING EN EWIGDURENDE HEERSKAPPY}

Dat Lukas Jesus se opstanding uit die dood en sy verheerliking in die hemel interpreteer as eskatologiese gebeure is alreeds duidelik uit Gabriël se aankondiging van Jesus se geboorte en toekomstige lot in Lukas 1:32-33:

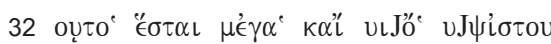

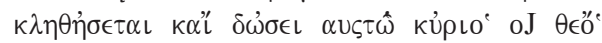

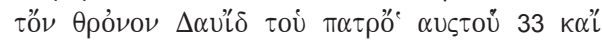

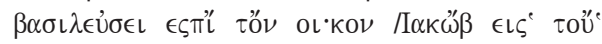

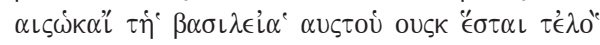

$32 \mathrm{Hy}$ sal groot wees en die Seun van die Allerhoogste genoem word. Die Here God sal Hom die troon van sy voorvader Dawid gee,

33 en Hy sal as koning oor die nageslag van Jakob heers tot in ewigheid. Aan sy koningskap sal daar geen einde wees nie.

Die eskatologiese karakter van Jesus se opstanding en hemelse troonbestyging as Dawidiese koning, is duidelik te sien uit die feit dat sy heerskappy vir ewig sal hou en sy koninkryk geen einde sal ken nie. Hierdie aankondiging is reeds vervul toe Lukas sy evangelie geskryf het en die spesifieke karakter van Jesus se eskatologiese heerskappy oortref elke Messiaanse verwagting in antieke Judaïsme.

Hier loop twee strome van Joodse eskatologiese hoop inmekaar: Een van hierdie strome is

17 Hierdie besonderse verwysing na Jesus vind ons slegs in Lukas se spesiale materiaal $(7: 13 ; 10: 39,41$; $13: 15 ; 16: 8 ; 18: 6 ; 19: 8)$ en as redaksionele byvoeging tot die materiaal van $Q(7: 19 ; 10: 1 ; 11: 39 ; 12: 42$; 17:5, 6) en van Markus (22:61; 24:3); vgl. de la Potterie (1970, 117-146); George (1978, 237vv.); Rowe (2006, 119v). 
die verwagting wat gebaseer is op Natan se belofte (vgl. 2 Sam 7:13, 16; Ps 89:3-5; 132: 11f; Jes 9:6; Eseg 37:25; PsSal 17:4; 1 Makk 2:57): die Dawidiese dinastie sal vir ewig bestaan en die lyn Dawidiese konings wat regeer oor Israel sal nooit verbreek word nie. In Gabriël se aankondiging word hierdie verwagting saamgevat in een individuele Dawidiese koning, wat terselfdertyd impliseer dat hy geen opvolger sal hê nie. Dit is nie net die Dawidiese dinastie wat vir ewig sal aanhou nie, meer een en dieselfde Messiaanse koning. Deur hierdie aankondiging beklemtoon Lukas dat die Skrif se beloftes hulle onweerlegbare en finale - dit wil sê eskatologiese - vervulling kry in Jesus, wat selfs die stigter van die Dawidiese dinastie oortref. Dit is vanselfsprekend dat dit slegs deur die opstanding is wat ' $n$ nimmereindigende heerskappy van een en dieselfde persoon teweeg gebring kan word, terwyl op die aarde slegs sterflike konings heers. Hier het ons 'n goeie voorbeeld van die twee vlakke van realiteit van eskatologiese beskouings.

Die ander stroom is net so belangrik: in soverre as wat dit gesê word dat Jesus se $\beta \alpha \sigma \iota \lambda \in i \alpha$ nooit sal eindig nie, word 'n karaktertrek wat tradisioneel met God geassosieer word op hom oorgeplaas aangesien ewigdurende kontinuïteit tot hier toe net toegeskryf is aan die koninkryk van God (vgl. bv., Ps 145:13; 146:10; Miga 4:7; Dan 2:44; 3:33; 4:31; 6:27; PsSal 17:1, 3, 46; Jub 1, 28; 1 Hen 84, 2; OrSib 3.49v.). Dit is net die Seun van die mens en die 'heilige volk van die Allerhoogste' aan wie soortgelyke verwagtings toegeskryf word volgens Daniël 7:14 en 27. Die kritieke eskatologiese belangrikheid van Jesus se opstanding en hemelse troonbestyging vir Lukas - en ek waag om te sê vir elke Christen - kan verklaar word deur twee verdere gevolge.

Aangesien Jesus se opstanding ' $n$ integrale deel van sy totale bediening vorm as eskatologiese gebeurtenis, is Conzelmann se beperking van die verhaal van Jesus tot ' $n$ gedane verlede ' $n$ fundamentele misverstaan van Lukas se teologie. Jesus se aardse bediening is Israel en sy teenswoordige heerskappy oor die huis van Jakob, behoort onlosmaaklik aan mekaar. Net soos die aardse bediening van Jesus in die verlede eskatologiese betekenis het, so het sy huidige hemelse heerskappy. Dit was die opstanding van Jesus wat die vooronderstellings teweeg gebring het om die eskatologiese karakter van sy bediening uit te brei verby sy dood tot in die huidige geskiedenis van Israel. En dit is in hierdie gees, wat nie bloot net ' $n$ plaasvervanger is vir die eschaton nie, maar die aardse verteenwoordiging van Jesus se eskatologiese heerskappy tussen sy gemeenskap van dissipels. ${ }^{18}$

Die tweede onmisbare funksie van die opstanding vir die verstaan van Jesus se totale bediening verhoed dat hy en sy bediening verstaan word in terme van ' $n$ tradisionele Joodse messiaanse hoop; d.i. as ' $n$ nasionale bevrydingsbeweging. Dit is moontlik om hierdie aspek uit twee verskillende gesigspunte te beskryf: met betrekking tot die 'konteks van ontdekking' (Entdeckungszusammenhang) moes Lukas daarin slaag om die spanning te handhaaf tussen sy verdediging van die teologiese aanspraak dat Jesus Israel se messiaanse verlosser is aan die een kant, en aan die ander kant, die historiese feit dat hy duidelik nie Jerusalem en Israel gered het uit vreemde heerskappy gedurende sy aardse heerskappy nie. Met betrekking tot die 'konteks van verduideliking' (Begründungs-zusammenhang), waarvolgens dit 'n misverstand is om die vervulling van Israel se hoop te verwag bloot net deur die aardse bediening van Jesus en om nie sy opstanding in te sluit by eskatologiese beslissings nie.

Lukas verwys kortliks na hierdie aspek in die inleiding tot die gelykenis van die troonaanspraakmaker in 19:11, wat vertel word om mense se misverstand te korrigeer dat - omdat Jesus naby Jerusalem was, die koninkryk van God onmiddellik sou verskyn - en hy ontwikkel hierdie aspek uitdruklik op die pad na Emmaus (24:17-24). In verse 19c-21a beskryf die twee dissipels Jesus aanvanklik as 'n profeet wat homself onderskei het deur sy woorde en dade. Met hierdie karakterisering skiet hulle ver tekort aan wie Jesus regtig is. Deur hierdie opinie aan te wend wys Lukas duidelik wat oor is van Jesus se bediening na sy dood (v. 20);

18 Vgl. die bydrae van Urich Busse in hierdie volume. 
indien hy bloot verwag word - soos wat die twee dissipels in die begin verwag het - om Israel se politiese verlossing teweeg te bring (v. 21); die herinnering is van ' $n$ baie gerespekteerde en indrukwekkende slot tot sy lewe - maar niks meer nie. Indien Israel se eskatologiese hoop slegs gerig is op die aardse bediening van Jesus, word hulle radikaal weerlê deur sy lyding en dood die tradisionele lot van Israel se profete. In kontras hiermee maak vers 26 dit duidelik dat sonder Jesus se opstanding uit die dood is daar geen vervulling van Israel se eskatologiese verwagtings nie. So lank as wat hierdie onmisbare verbintenis nie in gedagte gehou word nie, degradeer Jesus se lyding en dood hom bloot tot niks meer as'n 'profeet wat magtig was in woord en daad voor God en die hele volk'.

Ter opsomming: ja, Jesus is die messiaanse koning op wie Israel se eskatologiese hoop gerig was; en hy gaan beslis Jerusalem verlos en God se volk red van vreemde heerskappy en die koninkryk van Israel herstel. Maar, hy sal dit doen op ' $n$ manier wat totaal anders is as wat oorspronklik verwag is deur sy mede-Jode en die Emmaus dissipels. Dis sal gebeur wanneer die Seun van die mens 'kom, beklee met sy heerlikheid en die heerlikheid van die Vader en van die heilige engele' (9:26; vgl. ook 21:26). En daarby sal Israel 'n totaal ander vorm aanneem as wat dit gehad het in die tyd van Jesus: dit sal bestaan uit almal wat glo en wat geglo het in Jesus as eskatologiese verlosser wat God vir Israel gebring het (Hand 13:23; vgl. ook 3:23). Hiermee het ons gekom by die vraag wat die hooffokus was van werk in die Lukas departement vir verskeie dekades in die 'eskatologiese kantoor' (Troeltsch): die soeke vir die wanneer van die parousia en die uitstel daarvan.

\section{DIE SOEKTOG NA TYD}

Hierdie deel kan kort wees, want hierdie probleem is sterk gedebatteer vir meer as drie dekades sedert die bogenoemde studie van Conzelmann; ${ }^{19}$ en kan nou beskou word as afgehandel. Die parousia van die verheerlikte Here, soos dit belowe is in Handelinge 1:11, moet nog kom; maar Lukas weet nie wanneer dit sal gebeur nie. Lukas is ook nie seker dat daar lank gewag sal moet word nie, aangesien hy dink dat die Seun van die mens binne die volgende paar dae mag kom. Aan die ander kant, kan dit nie beslis gesê word dat hy hierdie koms in sy eie tyd verwag het nie, aangesien hy die moontlikheid oorweeg dat die parousia uitgestel kan word vir'n onberekenbare lengte van tyd. ${ }^{20}$

Selfs Lukas 18:7-8, waar Lukas se Jesus belowe dat God 'aan sy uitverkorenes ... reg sal

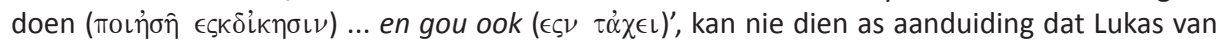
gedagte was dat die parousia om die draai was nie, aangesien hierdie aankondiging verwys na die vernietiging van Jerusalem: die waarskynlikheid van hierdie interpretasie word gesien in die feit dat in 21:22 Lukas hierdie gebeurtenis karakteriseer as byvoeging tot sy Vorlage (Mar 13:1617) en deurdat Hosea 9:7 aangehaal word as 'die tyd (letterlik die dae) van afrekening' ( $\eta J \mu ' \epsilon \rho \iota$ $\left.\epsilon \zeta \kappa \delta \iota \kappa \eta ் \epsilon \omega^{c}\right)$.

Aan die ander kant sluit die waarskuwing in Lukas 21:8 ('Pas op dat julle nie mislei word nie,

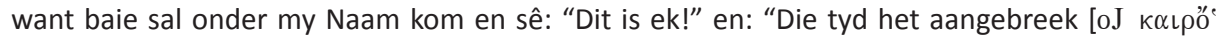

19 Die volgende boeke en artikels gee hieraan aandag: Conzelmann (1977); Flender (1968); Wilson (1969/1970, 330-347); Ellis (1972); Dupont (1973, 37-47); Hiers (1974, 145-155); Schneider (1975); Ernst (1978); George (1978, 285vv.); Mattill (1979); Grässer (1979, 99-127); Schnackenburg (1985, 249265); Erlemann (1995, 157-174); Onuki (2004, 186-198); vgl. ook die omvattende verslag van Plümacher (1983, 1-56, hier 35vv.).

20 Teen bv. Mattill $(1979,111)$ : 'He still believes in the return and does not expect it to be long delayed', en: 'That Luke's imminent hope could be denied is one of the marvels of modern criticism' (112); Erlemann $(1995,167)$. 


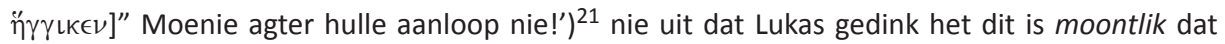
die tyd van die parousia ver weg was nie: die Jesus in Lukas waarsku sy hoorders - en moontlik ook die lesers van Lukas se evangelie - om nie te maklik beïndruk te wees met die boodskap van sommige messiaanse profete ${ }^{22}$ en hulle te volg nie. Indien hierdie boodskap 'n verwysing is na Lukas se lesers, is die waarskuwing gerig teen diegene wat onrus gesaai het aangaande die Christelike parousia soos diegene wat genoem word in 2 Tessalonisense 2:2 en in Hippolyt, Comm. in Daniël 4:19. Die twee slagspreuke funksioneer primêr as 'n karakterisering van dié profete en sekondêr die aanvoer dat die tyd van die parousia nog vêr is nie. Lukas los eenvoudig die vraag oop, eendag sal dit beslis naby wees.

Die oplossing vir die probleem word voorsien deur 21:25-31. Volgens vers 31 kan die finale verlossing herken word as 'naby' wanneer die gebeure wat beskryf word in verse 25-28 sal plaasvind. Die vraag oor die wanneer van die parousia is eenvoudig misplaas, want niks word gesê oor die temporele afstand van hierdie gebeure nie: dit mag wees dat hulle net om die hoek is, maar dit mag ook wees dat dit nie is nie. Selfs die apostels is nie toegelaat 'om die tyd en omstandigheid te weet wat die Vader in sy eie mag bepaal het nie' (Hand 1:7); en Lukas is beslis nie verhewe bo die apostels nie - nog minder is die lesers van sy evangelie (vgl. ook Wolter 1999, 307-324).

'n Besonderse probleem in hierdie konteks word op die tafel gesit deur vers 32, waar Lukas se Jesus sê dat 'hierdie geslag (hJ genea; au\{th) sal sekerlik nie verbygaan voordat alles gebeur het nie $\left(\epsilon^{\prime \prime} \omega^{\prime} \ddot{\alpha} \nu \pi \dot{\alpha} \nu \tau \alpha \gamma^{\prime} \epsilon \eta \tau \tau \iota\right)^{\prime}(\mathrm{OV})$. Die kritiese vraag is ongetwyfeld die betekenis en verwysing van 'hierdie geslag' ( $\left.\eta \in \mathcal{\epsilon} \epsilon_{\alpha}^{\prime} \alpha \mathcal{U}^{\prime \prime} \tau \eta\right) .23$ Dit is redelik onwaarskynlik dat Jesus se tydgenote bedoel word, want toe Lukas geskryf is was hulle reeds dood; die tekens van vers 25 het ook nog nie plaasgevind nie en die Seun van die mens het ook nie gekom nie. Sommige neem aan Lukas verwys na die mensdom in die algemeen,24 of die generasie mense wat toe geleef het,25 maar dit sou heeltemal niksseggend wees: die versekering dat die mensdom nog sal leef wanneer die

Seun van die mens kom vereis beslis nie so plegtige inleiding soos $\alpha \varsigma \mu \eta^{\prime} \nu \lambda^{\prime} \hat{\gamma} \gamma \omega \mu \mathrm{u}$ nie. Daarom is dit baie waarskynlik dat $\gamma \in \mathcal{\nu} \epsilon \dot{\alpha}$ nie 'n temporele verwysing is nie, maar aanduiding is van ' $n$ 'spesie' of 'persone in ' $n$ familie',26 en as verwysend na die dissipels van Jesus in die wydste sin van die woord.27 in hierdie geval waarborg Lukas se Jesus sy dissipels - en sy lesers ook - dat tot die Seun van mens kom sal die 'Christen spesie' nie uitsterf nie.

Aan die ander kant plaas hierdie waarborg 'n verpligting op die Christene in Lukas 21:34-36:

Wees op julle hoede dat julle gees nie deur onmatige etery en drinkery en deur die sorge van die lewe afgestomp word nie en dat daardie dag julle nie onverhoeds soos ' $n$ vangnet oorval nie. Daardie dag sal skielik op al die bewoners van die hele aarde neerkom. Maar wees waaksaam en bid altyddeur dat julle die krag kan ontvang om deur al hierdie dinge wat gaan gebeur, behoue deur te kom en om voor die Seun van die mens te verskyn.

Veral 12:35-48 wys duidelik dat Lukas die vraag oor die tyd van die eskatologiese voleinding van die wêreld en die vraag oor die uitstel van die parousia verander het tot ' $\mathrm{n}$ vraag oor die

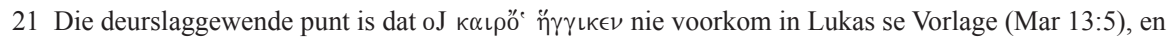
dat Lukas op sy beurt Markus 1:15 weglaat, waar Jesus verklaar dat 'Die tyd het aangebreek, en die

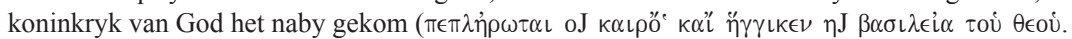

22 Vgl. Handelinge 5:36; 21:38; Josephus, Bell. 2:258-262; 6:285, 288; 7:437-440; Ant. 18:85-87; 20:97f, 167f, 170, 188.

23 Vgl. die oorsig van interpretasies deur Maddox (1982, 111vv.) en Bock (1996, 1688vv.).

24 Vgl., onder andere, Conzelmann (1977, 281v.).

25 Vgl., onder andere, Schneider (1980, 60); Fitzmyer (1985, 1353); Bock (1996, 1691v).

26 Liddell, Scott \& Jones (1992, 342 s.v. geneav I).

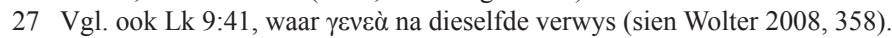


korrekte optrede in die lewe van Christene: hulle moet altyd gereed wees soos diensknegte wat die terugkeer van hulle afwesige meester enige oomblik verwag. Dit is genoodsaak vanweë die feit dat hulle oplaas nie weet wat die datum is van hulle meester se terugkeer nie.

\section{SLOTOPMERKINGS}

Die voorafgaande afdelings stel ons in staat om die unieke profiel van Lukas se konsep van die eskatologie op te som in 'n paar sinne: Lukas se eskatologiese denke hou gedeeltelik verband met die feit dat, sedert die tyd van Jesus, die finale lot van die mensdom en die wêreld nog nie aangebreek het nie en omdat Christene nog wag vir die parousia van die Seun van die mens. In reaksie op hierdie situasie ontwikkel Lukas 'n konsep wat hom toelaat om eskatologie te konseptualiseer - soos gepostuleer is aan die begin van hierdie artikel - as primêr bepaal deur kwaliteit; en slegs sekondêr deur tyd. Om in hierdie sin 'eskatologies' te bestaan beteken dat Christene altyd moet leef asof die Seun van die mens agter die deur staan. Hieruit volg dat: in terme van tyd, is eskatologie ingesluk deur etiek; d.i. deur die soeke vir die gepaste lewenswyse. Die teologiese belangrikheid van die eskatologie word slegs ontwikkel as deel van Lukas se Christologie.

\section{BRONNE GERAADPLEEG}

Aune, D.E. 1998 Revelation 17-22, WBC 52c Nashville.

Barth, K. 1922 Der Römerbrief, München.

Barth, K. 1933The Epistle to the Romans, translated from the sixth edition by E.W. Hoskyns Oxford/London. Bock, D.L. 1996 Luke II, BECNT 3 Grand Rapids, MI.

Bultmann, R. 1954/55 History and Eschatology in the New Testament, NTS 15-16.

Conzelmann, H. 1977 Die Mitte der Zeit, BHTh 17 Tübingen.

de la Potterie, I. 1970 Le titre KYRIOS appliqué à Jésus dans l'évangile de Luc, in: Mélanges bibliques en hommage au R. Béda Rigaux, Gembloux 117-146.

Dixon, L. 2003 The Other Side of the Good News, Ross-shire.

Dupont, J. 1973 Die individuelle Eschatologie im Lukasevangelium und in der Apostelgeschichte, in: Orientierung an Jesus, FS Josef Schmid Freiburg et alii 37-47.

Ebeling, G. 1979 Dogmatik des christlichen Glaubens III, Tübingen.

Ellis, E.E. 1972 Eschatology in Luke, Philadelphia.

Engnell, I. 1955 "Knowledge" and "Life" in the Creation Story, in: Wisdom in Israel and in the Ancient Near East FS Harold Henry Rowley, VT.S 3 Leiden 103-119.

Ernst, J. 1978 Herr der Geschichte. Perspektiven der lukanischen Eschatologie, SBS 88 Stuttgart.

Erlemann, K. 1995 Naherwartung und Parusieverzögerung im Neuen Testament, TANZ 17; Tübingen/Basel 157-174.

Filoramo, G. 1999 Art. Eschatologie. I. Religionswissenschaftlich, RGG (4th ed.) II 1542-1546.

Fitzmyer, J.A. 1985 The Gospel according to Luke II, AncB 28a Garden City NY.

Flender, H. 1968 Heil und Geschichte in der Theologie des Lukas, BEvTh 41 München.

Friedl, A. 1996 Das eschatologische Gericht in Bildern aus dem Alltag, ÖBS 14 Frankfurt a.M. et alii.

Geiger, R. 1973 Die Lukanischen Endzeitreden, EHS.T 16 Bern/ Frankfurt a.M. 53-149.

George, A. 1978 Études sur l'œuvre de Luc, Paris.

Grässer, E. 1977 Das Problem der Parusieverzögerung in den synoptischen Evangelien und in der Apostelgeschichte, BZNW 22 Berlin /New York.

Grässer, E. 1979 Die Parusieerwartung in der Apostelgeschichte, in: Les Actes des Apôtres. Traditions, rédaction, théologie, J. Kremer (éd.) BEThL 48 Gembloux/Leuven, 99-127.

Härle, W. 1995 Dogmatik, Berlin/New York.

Hiers, R.H. 1974 The Problem of the Delay of the Parousia in Luke-Acts, NTS 20 145-155.

Hjelde, S. 1987 Das Eschaton und die Eschata. Eine Studie über Sprachgebrauch und Sprachverwirrung in 
protestantischer Theologie von der Orthodoxie bis in die Gegenwart, BEvTh 102 München.

Klein, G. 1982 Art. Eschatologie. IV. Neues Testament, TRE X 270-299.

Konradt, M. 2003 Gericht und Gemeinde. Eine Studie zur Bedeutung und Funktion von Gerichtsaussagen im Rahmen der paulinischen Ekklesiologie und Ethik im 1 Thess und 1 Kor, BZNW 117 Berlin/New York.

Korn, M. 1993 Die Geschichte Jesu in veränderter Zeit, WUNT II/51 Tübingen.

Kümmel, W.G. 1972 Lukas in der Anklage der heutigen Theologie, ZNW 63, 149-165.

Liddell, H.G., R. Scott, H.S. Jones 1992 A Greek English Lexicon, Oxford.

Maddox, R. 1982 The Purpose of Luke-Acts, FRLANT 126 Göttingen.

Mattill, A.J. 1979 Luke and the Last Things. A Perspective for the Understanding of Lukan Thought, Dillsboro, NC.

Michel, D. 1968 Die Schöpfungsgeschichten, in: Israels Glaube im Wandel, idem. Berlin 101-148.

Nielsen, A.E. 2000 Until it is Fulfilled. Lukan Eschatology According to Luke 22 and Acts 20, WUNT 2/126 Tübingen.

Onuki, T. 2004 Christologie und Eschatologie in der lukanischen Theologie, in: Heil und Erlösung. Studien zum Neuen Testament und zur Gnosis, ibid. WUNT 165 Tübingen 186-198.

Plümacher, E. 1983 Acta-Forschung 1974-1982, ThR 48 1-56.

Rigaux, B.1970 La petite apocalypse de Luc (XVII,22-37), in: Ecclesia a Spiritu Sancto edocta, FS Gérard Philips BEThL 27, Gembloux 407-438.

Rowe, C.K. 2006 Early Narrative Christology: The Lord in the Gospel of Luke, BZNW 139 Berlin/New York. Sauter, G. 1995 Einführung in die Eschatologie, Darmstadt.

Schnackenburg, R. 1970 Der eschatologische Abschnitt Lk 17,20-37, in: Mélanges bibliques en hommage au R. Béda Rigaux, Gembloux 213-234.

Schnackenburg, R. 1985 Die lukanische Eschatologie im Lichte von Aussagen der Apostelgeschichte, in: Glaube und Eschatologie, FS Werner Georg Kümmel Tübingen 249-265.

Schneider, G. 1975 Parusiegleichnisse im Lukasevangelium, SBS 74 Stuttgart.

Schneider, G. 1980 Die Apostelgeschichte I, HThK 5/1 Freiburg et alii.

Tuckett, C.M. 1996 Luke, Sheffield.

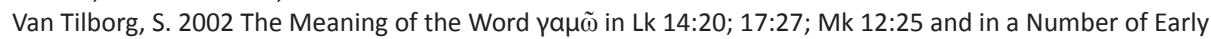
Jewish and Christian Authors, HTS 58 802-810.

Westermann, C. 1984 Genesis 1-11. A Commentary, translated by J.J. Scullion London.

Wilson, S.G.1969/70 Lukan Eschatology, NTS 16 330-347.

Wolter, M. 1999 Israel's Future and the Delay of the Parousia, according to Luke, in: D. Moessner (Ed.), Jesus and the Heritage of Israel, Harrisburg PA 307-324.

Wolter, M. 2000 Die Hirten in der Weihnachtsgeschichte (Lk 2,8-20), in: Religionsgeschichte des Neuen Testaments FS Klaus Berger Tübingen/Basel 501-517.

Wolter, M. 2008 Das Lukasevangelium, HNT 5 Tübingen.

Zmijewski, J. 1972 Die Eschatologiereden des Lukas-Evangeliums, BBB 40 Bonn 326-540.

\section{TREFWOORDE}

Eskatologie

Lukas Evangelie

Lukaanse eskatologie

Etiek

\section{KEY WORDS}

Eschatology

Gospel of Luke

Lucan eschatology

Ethics 